\title{
Board Gender Diversity, Earnings Quality and Stock Price Informativeness
}

\author{
Yue Gao \\ Department of Accounting, School of Business Administration, South China University of Technology, Guangzhou, China \\ Email: 1223784166@qq.com
}

How to cite this paper: Gao, Y. (2018) Board Gender Diversity, Earnings Quality and Stock Price Informativeness. American Journal of Industrial and Business Management, 8, 306-312. https://doi.org/10.4236/ajibm.2018.82018

Received: January 3, 2018

Accepted: February 11, 2018

Published: February 14, 2018

Copyright $\odot 2018$ by author and Scientific Research Publishing Inc. This work is licensed under the Creative Commons Attribution International License (CC BY 4.0).

http://creativecommons.org/licenses/by/4.0/

(c) (i) Open Access

\begin{abstract}
Further recognition of women's social value and the gradual improvement of women's economic status have made the proportion of female independent directors on board rise year by year, which has received high attention from academia. Using data of A-share listed companies in Shanghai and Shenzhen stock markets form 2000-2014 in China, this paper investigates the relation among gender diversity, earnings quality and stock price informativeness. As a result, the larger the proportion of female independent directors is, the more firm-specific information the stock price contains. In the meantime, earnings quality of listed companies significantly impact on stock price informativeness, which means that stock prices of companies with higher earnings quality contain more firm-specific information while having other factors controlled. Further studies show that the relation between board gender diversity and stock price informativeness is not simply direct; board gender diversity could raise the stock price informativeness through enhancing earnings quality.
\end{abstract}

\section{Keywords}

Stock Price Informativeness, Idiosyncratic Volatility, Board Gender Diversity, Earnings Quality

\section{Introduction}

Information disclosure is very important for the rational allocation of scarce economic resources and the healthy operation of the whole economic society in the present economic environment. Because the widespread existence of information asymmetry and uncertainty, people are eager for real and reliable information to make the optimal investment decision. The information displayed by stock price is very important for investors to make decisions, especially the company level information contained in stock price, which is the main basis for 
investors to identify each company's value. As a result, more and more people have changed their research direction on the information content of stock prices. The more information contained in the stock price, the stock price is much closer to the actual value of the enterprise. In that case, the money of investors will transfer form low utilization enterprises to high utilization enterprises.

In China, the economic development is faster and faster and capital market is on the right track after the reform and opening up. The investors in the market make the investment decision according to the information published in the financial statements of the company. If the stock price contains a lot of information at the company level, investors make more effectively decisions based on the volatility of the stock price. But the disclosure of financial statements may be interfered by the management of the company under the condition that the ownership of the company is separated from the management right. Management is motivated to manage earnings in order to control earnings quality for their own interests or other related interests. What is the relationship between the quality of the company's earnings and the information content of the stock price?

More and more female staffs have gained social identity and participate in business activities with the opening of the people's thought after the reform and opening up [1]. Daily, Certo and Dalton [2] concluded that the percentage of women's independent directors has increased significantly in the past ten years through the empirical research on the situation of women directors in the world's top 500 enterprises in 1987 and 1996, which proves that the "glass ceiling" phenomenon for women is gradually being evaded in the workplace. Although the identity of women in the occupational market is still lower than that of men, there is no doubt that the degree and participation of women are increasing. At the same time, public media also pay more attention to female leaders [3]. Whether the participation of female directors in the board will affect the quality of earnings? Whether it will affect the information content of the stock price? At last, will the increase of the proportion of female directors affect the company's earnings management, thereby affecting the company's stock price information content?

Adams and Ferreira [4] believed that the participation of female directors greatly improves the business performance of the company. Because men tend to have overconfidence in the information bias in the board of directors [5], when women join the decision-making group, the female character is complementary with men. Besides women will have some new ideas when making decisions, so that the company's management decision-making system is more perfect, and the company's performance goes up, so as to improve the company's earnings quality [6]. Huang Jicheng and Sheng Mingquan [7] think that executives' background characteristics have significant information content. The existence of gender differences in the board of directors can indeed increase the information content of stock prices. The correctness of the conclusion can be improved by analyzing the earnings information when the quality of earnings is improved. All 
in all, three hypothesis are presented in this paper: 1) The degree of gender diversification of directors can improve the information content of stock prices. 2) The earnings quality of the last phase can improve the information content of the stock price in this period. 3) The gender diversity of the board of directors will improve the information content of the stock price by improving the quality of the earnings.

As a result, the larger the proportion of female independent directors is, the more firm-specific information the stock price contains. In the meantime, earnings quality of listed companies significantly impact on stock price informativeness, which means that stock prices of companies with higher earnings quality contain more firm-specific information while having other factors controlled. Further studies show that the relation between board gender diversity and stock price informativeness is not simply direct; board gender diversity could raise the stock price informativeness through enhancing earnings quality.

\section{Empirical Study}

\subsection{Model Design}

The following models are used to investigate the relation among gender diversity, earnings quality and stock price informativeness, this model is used by Gul, Srinidhi and Ng in 2011 [8]:

$$
\begin{aligned}
\mathrm{IV}_{i, t}= & \beta_{0}+\beta_{1} \mathrm{FIDIR}_{i, t-1}+\beta_{2} \mathrm{EQ}_{i, t-1}+\beta_{3} \mathrm{EQ}_{i, t-1} \times \mathrm{FIDIR}_{i, t-1} \\
& +\beta_{4} \mathrm{ROE}_{i, t-1}+\beta_{5} \mathrm{LEV}_{i, t-1}+\beta_{6} \mathrm{MtoB}_{i, t-1} \times \beta_{7} \mathrm{IDIR}_{i, t-1} \\
& +\sum \text { Industry }+\varepsilon_{t}
\end{aligned}
$$

\subsection{Variable Definition}

According to the study of this paper, this article investigates the relation among gender diversity, earnings quality and stock price informativeness. So this paper designs the above model based on the hypothesis. Besides, IV represents the heterogeneous fluctuation of stock price; FIDIR represents the number of independent female directors; EQ represents earnings quality calculated by Model $\mathrm{DD}$; ROE represents the rate of return on capital equity; LEV represents financial leverage of the company; MtoB represents the market value ratio; IDIR represents the number of independent directors of the board of directors. Table 1 gives the definition of the variables involved in this article.

\subsection{Sample Selection}

This article selects data of A-share listed companies in Shanghai and Shenzhen stock markets form 2000-2014 in china, the data from CSMAR database. Table 2 shows the sample selection process. First, we eliminated the data of companies from the SME and GEM. Second, we eliminated the data of companies from Financial industry because for its particularity. Table 3 shows the industry distribution of the sample. The samples are divided into 12 industries according to the classification standards of the SFC. 
Table 1. Variable definition table.

\begin{tabular}{cccc}
\hline Variable type & Variable name & $\begin{array}{c}\text { Expected } \\
\text { symbol }\end{array}$ & Variable definition \\
\hline Interpreted variable & $\mathrm{IV}_{i, t}$ & & Heterogeneous fluctuation of stock price \\
Explanatory variable & $\mathrm{FIDIR}_{i, t-1}$ & + & Number of independent female directors \\
& $\mathrm{EQ}_{i, t-1}$ & + & Earnings quality \\
Control & $\mathrm{ROE}_{i, t-1}$ & $?$ & Rate of return on capital equity \\
variable & $\mathrm{LEV}_{i, t-1}$ & $?$ & Financial leverage \\
& $\mathrm{MtoB}_{i, t-1}$ & $?$ & Market value ratio \\
& $\mathrm{IDIR}_{i, t-1}$ & The number of independent directors of the board of directors \\
\hline $\mathrm{Industry}$ & & INDj \\
\hline
\end{tabular}

Table 2. Sample screening table.

\begin{tabular}{|c|c|c|c|c|c|c|c|c|c|c|c|c|c|c|}
\hline & All years & 2002 & 2003 & 2004 & 2005 & 2006 & 2007 & 2008 & 2009 & 2010 & 2011 & 2012 & 2013 & 2014 \\
\hline $\begin{array}{c}\text { A shares 2002-2014 } \\
\text { data }\end{array}$ & 16777 & 1062 & 1140 & 1204 & 1268 & 1317 & 1302 & 1316 & 1328 & 1330 & 1336 & 1365 & 1395 & 1414 \\
\hline $\begin{array}{c}\text { data wipe off } \\
\text { banking business }\end{array}$ & -342 & -15 & -16 & -18 & -19 & -19 & -19 & -24 & -31 & -31 & -63 & -37 & -40 & -40 \\
\hline $\begin{array}{c}\text { A shares 2002-2014 } \\
\text { data wipe off } \\
\text { banking business }\end{array}$ & 16435 & 1047 & 1124 & 1186 & 1249 & 1298 & 1283 & 1292 & 1297 & 1299 & 1303 & 1328 & 1355 & 1374 \\
\hline $\begin{array}{c}\text { Data wipe off Lag } \\
\text { phase }\end{array}$ & -1450 & 0 & -80 & -70 & -67 & -59 & -1 & -15 & -15 & -3 & -13 & -27 & -32 & -21 \\
\hline Final Sample & 14985 & 0 & 1044 & 1116 & 1182 & 1239 & 1282 & 1277 & 1282 & 1296 & 1290 & 1301 & 1323 & 1353 \\
\hline
\end{tabular}

Remarks: The data from CSMAR database.

Table 3. Sample distribution.

\begin{tabular}{|c|c|c|c|c|c|c|c|c|c|c|c|c|c|}
\hline Industry name & 2003 & 2004 & 2005 & 2006 & 2007 & 2008 & 2009 & 2010 & 2011 & 2012 & 2013 & 2014 & 合计 \\
\hline farming industry & 15 & 16 & 17 & 19 & 20 & 20 & 19 & 19 & 19 & 19 & 20 & 20 & 223 \\
\hline manufacturing industry & 526 & 574 & 613 & 651 & 678 & 674 & 670 & 671 & 667 & 672 & 683 & 706 & 7785 \\
\hline $\begin{array}{c}\text { Electricity, gas and water } \\
\text { Production and supply industry }\end{array}$ & 54 & 57 & 61 & 63 & 70 & 70 & 71 & 71 & 71 & 72 & 73 & 74 & 807 \\
\hline construction industry & 18 & 20 & 22 & 25 & 28 & 28 & 28 & 30 & 30 & 33 & 32 & 36 & 330 \\
\hline $\begin{array}{l}\text { Transportation and } \\
\text { warehousing industry }\end{array}$ & 43 & 46 & 51 & 57 & 57 & 57 & 62 & 65 & 64 & 65 & 70 & 70 & 707 \\
\hline $\begin{array}{l}\text { Information technology } \\
\text { industry }\end{array}$ & 48 & 51 & 53 & 58 & 59 & 59 & 58 & 58 & 58 & 58 & 59 & 58 & 677 \\
\hline real estate & 115 & 119 & 123 & 124 & 125 & 125 & 127 & 127 & 126 & 126 & 126 & 126 & 1489 \\
\hline Social service industry & 36 & 36 & 38 & 38 & 38 & 38 & 39 & 39 & 39 & 40 & 40 & 40 & 461 \\
\hline $\begin{array}{l}\text { Communication and cultural } \\
\text { industry }\end{array}$ & 13 & 13 & 14 & 14 & 13 & 13 & 13 & 14 & 14 & 15 & 16 & 17 & 169 \\
\hline Comprehensive industry & 30 & 28 & 28 & 25 & 24 & 24 & 24 & 24 & 23 & 23 & 23 & 23 & 299 \\
\hline
\end{tabular}

Remarks: The data from Wind database. 


\section{Analysis of Empirical Results}

This paper investigates the relation among gender diversity, earnings quality and stock price informativeness using the least square method. Table 4 shows the empirical results.

Model (1) first verifies whether there is a direct relationship between FIDIR, a female independent director, and heterogeneous fluctuation of stock price (IV). The results show that without any control of other variables, the larger the number of female directors in the board, the stronger the heterogeneous fluctua-

Table 4. Model regression results.

\begin{tabular}{|c|c|c|c|c|c|c|}
\hline Variable & $\begin{array}{l}\text { Model (1) } \\
\text { (t) }\end{array}$ & $\begin{array}{l}\text { Model (2) } \\
(\mathrm{t})(\mathrm{VIF})\end{array}$ & $\begin{array}{l}\text { Model (3) } \\
\text { (t) }\end{array}$ & $\begin{array}{l}\text { Model (4) } \\
\text { (t) (VIF) }\end{array}$ & $\begin{array}{l}\text { Model (5) } \\
\text { (t) (VIF) }\end{array}$ & $\begin{array}{c}\text { Model (6) } \\
\text { (t) (VIF) }\end{array}$ \\
\hline \multirow[t]{2}{*}{ Intercept } & $0.3792^{* * *}$ & $0.1991^{\star * *}$ & $0.4797^{\star \star \star}$ & $0.2522^{\star * *}$ & $0.4550^{* * *}$ & $0.2434^{* * *}$ \\
\hline & $(47.84)$ & $(7.38)$ & $(60.59)$ & $(7.02)$ & $(47.20)$ & $(6.76)$ \\
\hline \multirow[t]{3}{*}{ FIDIR } & $0.0887^{\star * *}$ & $0.0473^{\star * \star}$ & & & $0.0677^{\star * *}$ & $0.0530^{\star * \star}$ \\
\hline & $(7.66)$ & $(4.33)$ & & & $(4.95)$ & $(4.13)$ \\
\hline & & $(1.05)$ & & & $(1.35)$ & $(1.37)$ \\
\hline \multirow[t]{3}{*}{ EQ } & & & $0.0150^{\star * *}$ & $0.0146^{\star * *}$ & $0.0133^{* * *}$ & $0.0126^{* * *}$ \\
\hline & & & $(9.37)$ & $(8.90)$ & $(6.80)$ & $(6.36)$ \\
\hline & & & & $(1.11)$ & $(1.47)$ & $(1.59)$ \\
\hline \multirow[t]{3}{*}{$\mathrm{EQ} \times$ FIDIR } & & & & & 0.0044 & $0.0049^{*}$ \\
\hline & & & & & $(1.56)$ & $(1.73)$ \\
\hline & & & & & $(1.82)$ & $(1.83)$ \\
\hline \multirow[t]{3}{*}{ ROE } & & $-0.7299^{\star * *}$ & & $-0.7110^{\star * *}$ & & $-0.7104^{\star * *}$ \\
\hline & & $(-23.05)$ & & $(-21.94)$ & & $(-21.93)$ \\
\hline & & $(1.01)$ & & $(1.02)$ & & $(1.02)$ \\
\hline \multirow[t]{3}{*}{ LEV } & & $-0.2925^{\star * *}$ & & $-0.2620^{* * *}$ & & $-0.2677^{* * *}$ \\
\hline & & $(-4.40)$ & & $(-3.85)$ & & $(-3.94)$ \\
\hline & & $(1.08)$ & & $(1.11)$ & & $(1.11)$ \\
\hline \multirow[t]{3}{*}{ MtoB } & & $-0.1993^{\star * *}$ & & $-0.1206^{\star * *}$ & & $-0.1169^{* * *}$ \\
\hline & & $(-7.33)$ & & $(-4.43)$ & & $(-4.29)$ \\
\hline & & $(1.09)$ & & $(1.08)$ & & $(1.08)$ \\
\hline \multirow[t]{3}{*}{ IDIR } & & $0.1156^{* * *}$ & & $0.0998^{* * *}$ & & $0.0954^{* * *}$ \\
\hline & & $(18.40)$ & & $(10.93)$ & & $(10.43)$ \\
\hline & & $(1.10)$ & & $(1.08)$ & & $(1.10)$ \\
\hline ¿Industry & Uncontrolled & Controlled & Uncontrolled & Controlled & Uncontrolled & Controlled \\
\hline $\mathrm{N}$ & 14985 & 14370 & 13559 & 12968 & 13559 & 12968 \\
\hline $\operatorname{Adj}-R^{2}$ & 0.0037 & 0.0833 & 0.0053 & 0.0736 & 0.0071 & 0.0748 \\
\hline $\mathrm{F}$ & 58.61 & 71.61 & 87.86 & 55.18 & 38.77 & 50.45 \\
\hline
\end{tabular}

${ }^{* * *}$ stands for a significant level of $1 \%$. 
tion of the company's stock price, and the more information contained in the stock price. Model (2) adding control variables such as ROE, LEV, MtoB, IDIR, industry dummy variable on the basis of model (1), results show that there is no change in the relation between the number of independent female directors FIDIR and heterogeneous fluctuation of stock price. The correlation coefficient is 0.0473 , and it is significant at the level of $1 \%$.

The model (3) verifies whether the earnings quality directly affects the heterogeneous fluctuation of stock price, and finds that the higher the earnings quality, the stronger the heterogeneous fluctuation of the company's stock price. Model (4) uses heterogeneous fluctuation of stock price as the Interpreted variable, and the explanatory variable introduces the earnings quality EQ and the control variables ROE, LEV, MtoB, IDIR and industry dummy variable $\Sigma$ Industry, and the results are consistent with Model (3).

The model (5) takes the number of independent female directors FIDIR; earnings quality EQ and the multiplication of FIDIR and EQ EQ $\times$ FIDIR as explanatory variables, the heterogeneous volatility of information content in stock prices IV as interpreted variable. The results show that the regression coefficients of FIDIR and earnings quality EQ are 0.4550 and 0.0667 , and they are all significant at the level of $1 \%$. But, the multiplication of FIDIR and EQ EQ $\times$ FIDIR is not significant. All variables (including control variables) are put in the equation in the Model (6), and the regression coefficients of FIDIR, EQ and $\mathrm{EQ}^{\star}$ FIDIR are all positive, and all of them pass the Test $\mathrm{T}$.

\section{Conclusion}

The influence of female directors on the information content of stock prices has been studied by many people, but is there any other intermediary variable in the relationship between female director and stock price informativeness? This paper is based on the previous studies on the relation between gender diversity in the board and stock price informativeness, further study the relation among gender diversity in the board, earnings quality and stock price informativeness. Using data of A-share listed companies in Shanghai and Shenzhen stock markets form 2000-2014 in China, this paper investigates the relation among gender diversity, earnings quality and stock price informativeness. As a result, the larger the proportion of female independent directors is, the more firm-specific information the stock price contains. In the meantime, earnings quality of listed companies significantly impact on stock price informativeness, which means that stock prices of companies with higher earnings quality contain more firmspecific information while having other factors controlled. Further studies show that the relation between board gender diversity and stock price informativeness is not simply direct; board gender diversity could raise the stock price informativeness through enhancing earnings quality.

\section{References}

[1] Beaman, L., Chattopadhyay, R., Duflo, E., Pande, R. and Topalova, P. (2009) Po- 
werful Women-Does Exposure Reduce Prejudice. Quarterly Journal of Economics, $1-52$.

[2] Daily, C.M., Certo, S.T. and Dalton, D.R. (1999) Research Notes and Communications a Decade of Corporate Women: Some Progress in the Boardroom, None in the Executive Suite. Strategic Management Journal, 20, 93-99.

https://doi.org/10.1002/(SICI)1097-0266(199901)20:1<93::AID-SMJ18>3.0.CO;2-7

[3] Lee, P.M. and James, E.H. (2007) She-e-os: Gender Effects and Investor Reactions to the Announcements of Top Executive Appointments. Strategic Management Journal, 28, 227-241. https://doi.org/10.1002/smj.575

[4] Adams, R.B. and Ferreia, D. (2009) Women in the Boardroom and Their Impact on Governance. Journal of Financial Economics, 94, 291-309.

https://doi.org/10.1016/j.jfineco.2008.10.007

[5] Huang, J.K. and Kisgen, D.J. (2013) Gender and Corporate Finance-Are Male Executives Overconfident Relative to Female Executives. Journal of Financial Economics, 108, 822-839. https://doi.org/10.1016/j.jfineco.2012.12.005

[6] Kogut, B., Colomer, J. and Belinkys, M. (2014) Structural Equality at the Top of the Corporation-Mandated Quotas for Women Directors. Strategic Management Journal, 35, 891-902. https://doi.org/10.1002/smj.2123

[7] Huang, J.C. and Sheng, M.Q. (2013) Do Executive Background Features Have Information Content. Management World, 9, 144-171.

[8] Gul, F.A., Srinidhi, B. and Ng, A.C. (2011) Does Board Gender Diversity Improve the Informativeness of Stock Prices. Journal of Accounting and Economics, 51, 314 338. https://doi.org/10.1016/j.jacceco.2011.01.005 